Journal of Southeast Asian

2013

\title{
Learning English and "Smartness": Refugee Students Negotiate Language, Reception, and Ability in School
}

Liv Thorstensson

University of Illinois, livtd@illinois.edu

Follow this and additional works at: https://docs.lib.purdue.edu/jsaaea

\section{Recommended Citation}

Thorstensson, Liv (2013) "Learning English and "Smartness": Refugee Students Negotiate Language, Reception, and Ability in School," Journal of Southeast Asian American Education and Advancement: Vol. 8 : Iss. 1, Article 1.

DOI: $10.7771 / 2153-8999.1056$

Available at: https://docs.lib.purdue.edu/jsaaea/vol8/iss1/1

This document has been made available through Purdue e-Pubs, a service of the Purdue University Libraries. Please contact epubs@purdue.edu for additional information.

This is an Open Access journal. This means that it uses a funding model that does not charge readers or their institutions for access. Readers may freely read, download, copy, distribute, print, search, or link to the full texts of articles. This journal is covered under the CC BY-NC-ND license. 


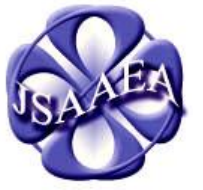

Volume 8 (2013)

\section{Journal of Southeast Asian American}

Education \& Advancement

WWW.JSAAEA.org
A peer-reviewed scholarly journal published by the National Association for the Education \& Advancement of Cambodian, Laotian, and Vietnamese Americans (NAFEA)

\title{
Learning English and "Smartness": \\ Liv Thorstensson Dávila \\ University of Illinois
} Refugee Students Negotiate Language, Reception, and Ability in School

\begin{abstract}
This article analyzes how Southeast Asian refugee high school students negotiated "smartness" and language learning at a low-performing, urban high school in the U.S. southeast. Findings are drawn from a year-long qualitative study that examined the identities of refugee students from Vietnam's Central Highlands. The conceptual framework is built on sociocultural theories of identity and language learning (Bourdieu, 1991; Holland, Skinner, Lachicotte \& Cain, 1998) and illuminates the contextual and relational nature of students' identity articulation in school. Findings underscore the ways in which racialized discourses perpetuated by teachers and peers simultaneously positioned them as model minorities and undermined their learning, and self-identities. Implications for policy and practices, as well as theoretical perspectives that deepen understandings of refugee identity and performance in school are proposed.
\end{abstract}

KEY WORDS: refugees, language learning, model minority, high school

\section{Introduction}

Sitting at a public library, I asked $\mathrm{Gar}^{1}$, a nineteen year-old high school junior from the Vietnamese Central Highlands, how she would describe herself in school:

I don't know...I am good in school, but I'm not smart. I am slow because I don't speak good English. I try hard but I don't understand my teacher[s]. I feel dumb. Teachers like me because I'm quiet, but they don't like me because I don't speak English.

Gar is a refugee who arrived in the U.S. with her family in 2003 and began her schooling and learning English at a local middle school. As an 11 year-old, she had had no prior formal schooling in Vietnam and did not read or write in her native language. Within the institutional context of school, she was a Limited English Proficient (LEP) Student with Interrupted Formal Education (SIFE).

\footnotetext{
(c) SOMERIGHISRESERVEDReaders are free to copy, display, and distribute this article, as long as the work is attributed to the author(s) and the Journal of Southeast Asian American Education \& Advancement, it is distributed for noncommercial purposes only, and no alteration or transformation is made in the work. More details of this Creative Commons license are available at http://creativecommons.org/licenses/by-nc-nd/3.0/. All other uses must be approved by the author(s) or JSAAEA.
} 
This article comes out of a year-long qualitative study on how Vietnamese Central Highlander refugee students negotiate their identities and language learning in school. My analysis of Gar and seven other high school refugee English Language Learners (ELLs) interrogates the notion of "smartness" as a social and cultural, rather than biological construct. Though the students frequently described themselves as being "smart" and "not smart," I argue that smartness is both overtly and covertly ascribed to others as a means of social positioning and control along the lines of language, socioeconomic status, and race. As a cultural practice, it is also a way of making sense of one's own identity, and abilities in school.

The students who lent their voices to this study grew up in rural Vietnam and spent time in refugee camps where access to schooling was limited. For these students, as for other immigrant and refugee students in the U.S., resettlement has entailed learning a new language, and how to be a student in an American school. Much research literature centers on the identities and adaptation of immigrant students (Duff, 2008; Harklau, 2000; Olsen, 1997; SuarezOrozco \& Suarez-Orozco, 2001; Valenzuela, 1999; Varghese, Morgan, Johnston, \& Johnson, 2005; Wortham, Murillo, \& Hamman, 2002). However, less scholarship has addressed identity paradigms of newcomer refugee students in school, and how learning and using a new language bears on their experiences in and expectations of school (exceptions include works by Bigelow (2010), Centrie (2004), Lee (1996, 2005), Mosselson (2006), and Talmy (2009)). What is more, in an era in which smartness is measured by performance on tests, and "common core" standards, few studies have examined how smartness is constructed at the social and institutional level.

Refugee students' first-hand accounts of language learning in school highlight some of the ongoing challenges with refugee resettlement in general, and their language learning and academic achievement in particular. Opportunities to attend school in the resettlement country can be especially significant for refugee students for whom access to school was previously limited or nonexistent; for refugee students, schools may represent a valuable source of intellectual, linguistic, and social capital. However, many refugees struggle to recover from trauma experienced in their countries of origin, or during the process of migration, or separation from family members, while also continuing to be socially, linguistically, and economically marginalized in a new context. Indeed, many refugees also tap into coping mechanisms and display resiliency in the face of loss, transition and adjustment (Anderson, 2004, as cited Hamilton \& Moore, 2004).

In this article, I explore how a group of refugee students with limited formal education negotiated the intersection between language learning, race, and perceptions of intelligence intelligibility in school. I specifically employ the term "smart" (and smartness) because of the frequency with which students used this term in my conversations with them. In particular, I examine smartness as a social and cultural construct embodied through ideology, institutional practices, social relationships and discourses. For refugee students with limited formal education, an examination of smartness as a social, and linguistic construct, as opposed to a biological one, assumes significant meaning related to acceptance, achievement, and aspiration. Considering that Asians have stereotypically been defined as "model minorities" in U.S. racial discourse, this article reveals how a group of refugees from Southeast Asia with limited, interrupted education both benefited from and were handicapped by this stereotype (Lee, 2007; Ngo \& Lee, 2007, Uy, 2009). Moreover, this study reveals the ways in which the students worked on the margins to creatively engage school practices and discourses. 


\section{Background}

\section{The Politics of Language Proficiency}

This research conceptualizes language learning as one of the crucial sites through which newcomer refugee students filter their identities and sense of opportunities and constraints in school. Language proficiency has long been regarded as a component of membership equated with patriotism, national identity, and a rightful place in society (Blommaert, 2006). Language is also used as a means of social stratification (Crawford, 2004). Lippi-Green argues:

What our schools do, for the most part, is to insist that some children forego the expressive power and consolation of speech in that variety of English which is the currency of their home communities. This gesture of denial and symbolic subordination is projected as a first and necessary step to becoming a good student and a good citizen. (1997, p. 132)

The master narrative that equates English not only with membership and patriotism, but also intelligence and future success influences dominant and minoritized groups alike. Policies, practices, and everyday interactions in American schools illustrate that for an individual to be considered a valuable member of and to hold status within a group they must speak unaccented, Standard American English.

Bourdieu (1977) has argued, "A person speaks not only to be understood but also to be believed, obeyed, respected, distinguished" (p. 648). Communicative competence, then, implies the "power to impose reception" (Norton, 1998); it is a multidirectional processes embedded in authority and power. The communicative competence suggested by Bourdieu is a product of social interaction. An "investment" (Norton Pierce, 1995) in developing proficiency in a new language does not guarantee that opportunities to do so will be available. Group membership frames the ways in which we see ourselves and the world, and carries the benefits and consequences related to status and self-esteem. Norton (2000) suggests that, "it is through language that a person negotiates a sense of self within and across different sites at different points in time, and it is through language that a person gains access to - or is denied access to powerful social networks that give learners the opportunity to speak" (p. 5).

While as a tool for recognition, language can also be seen as a "proxy" through which inequality is legitimated and reproduced (Skutnabb-Kangas \& Phillipson, 1994). Schools are primary sites for linguicism, or "language bigotry" (Valdés, 2001) because language ideology can be hidden behind the notion that all students must learn and produce "proper" English in order to be rightful citizens of an English-speaking nation. As a result, there is often less social and academic support than is needed for students who speak accented American English.

\section{Race, Discourse, and Positioning of Asian Students}

Although race is no longer used to legally enforce inequality, Lippi-Green's $(1997,2012)$ work on standard language ideology and accent illustrates how inequality influences communicative interactions, and that race is an important factor when assessing a non-native speaker's accent. Individuals are predisposed to evaluate a person of another race to be less competent when 
hearing them speak. Discourse on racial difference can influence the ways racial minorities are perceived and in turn perceive themselves.

Scholars of Asian American studies have argued that because U.S. racial discourse is most often framed in Black-White terms, Asian Americans are positioned as "honorary Whites," but also "forever foreigners"- as similar to the White majority, but as not belonging in the U.S. (Tuan, 1998). As a result, racial discrimination toward Asians is often overlooked in institutional settings. Scholars have also explored the "model minority" stereotype in relation to Asian immigrant students' self and positional identities in school (Centrie, 2004; Lee, 1996, 2005). A political concept put forth in the 1960s, the construct attributes academic and economic success among Asian Americans to cultural norms that place a high value on education. Lee (1996) has argued that this stereotype obscures variation across ethnic groups and individuals, and that students who live up to this stereotype are hailed, whereas students unable to meet these standards are deemed failures, or substandard for their race. In addition, by lauding the achievements of one group over another, the stereotype can create divisive relations between Asian students and their non-Asian peers.

In this article, I present an identity paradigm that focuses on being "smart" or "not smart" based on the intersection between English language proficiency and race that emerged out of interactions between refugee students from Vietnam, and their peers and teachers, as well as school practices which challenged their inherent notions of what it means to be successful in school.

\section{Theorizing "Smartness"}

In this study I define smartness as a cultural practice, as opposed to that it is biological or conferred through genetics (Gould, 1996). I employ the framework of positional identities (Holland, Skinner, Lachicotte \& Cain, 1998) as a means of engaging the ways in which newcomer ELL refugees internalize and negotiate messages around smartness, and how they draw on their own cultural and linguistic resources as they shape their trajectories in school. Positional identities:

have to do with how one identifies one's position relative to others', mediated through ways in which one feels comfortable or constrained, for example, to speak to another, to command another, to enter into the space of another, to touch the possessions of another, to dress for another (Holland et al., p. 150)

In addition, I use the construct of figured world to illustrate how smartness is contextual, relational, and rooted in power and privilege. Figured worlds are a "socially and culturally constructed realm of interpretation in which particular outcomes are valued over others," (Holland et al., 1998, p. 52) and within which identities are created enacted, assigned, and subverted. Students' self-identities are influenced by how they perceive of their positions within the figured world of school. Holland et al. (1998) argue that newcomers:

learn a feel for the game, for how such claims on their part will be received. They come to have relationship identities in their most rudimentary form: a set of dispositions toward themselves in relation to where they can enter, what they can way, what emotions they can have, and what they can do in a given situation. (p. 143) 
The ways in which schools construct what it means to be or not be smart can be particularly harmful for linguistically, racially, and economically marginalized youth. Valenzuela (1999) and Lee (2005), in their ethnographic studies of Mexican-American and Hmong students, found that these students were made to feel incompetent and unsuccessful through policies that placed them in vocational tracks, and teachers who negatively stereotyped them. Kinchloe, Steinberg and Villaverde (1999) argue for a greater understanding of how educational knowledge is rooted in unequal relationships of power that are particularly detrimental to "racially, ethnically, and economically marginalized students who are trying to figure out why they are deemed slow and incompetent in the schools they attend" (p. 11). My work extends these studies by looking at how language proficiency intersects with race and racial stereotypes to define intellect and academic ability as cultural practices.

\section{Research Site}

\section{Methodology}

This study took place at a high school located in a large metropolitan center in the U.S. southeast. Over 2,000 students attended the school during the period of this study, and the school's demographics were 70\% African American, 13\% White, 8\% Hispanic, 6\% Asian, 2\% Multiracial, and 1\% Native American. Seventy-one percent of the school's students received free/reduced lunch, $17 \%$ were designated as Students with Disabilities, and $8 \%$ were designated as Limited English Proficient (LEP). The school was recently termed one of the system's four "challenge schools" in the city's newspaper because of its consistently low scores on No Child Left Behind (NCLB) mandated state tests, and high poverty and drop-out rates.

The city was home to the state's largest population of Vietnamese Central Highlanders, and the majority of the city's high school aged Vietnamese Central Highlander refugee students (94 out of roughly 200) were enrolled at this school. Out of the 2,000 students at the school, 64 students self-identified as first-generation Vietnamese Central Highlanders. Growing numbers of Vietnamese Central Highlanders had failed to complete high school in recent years in spite of community efforts to reverse this trend. Knowing this, I was interested in understanding reasons behind this trend.

\section{Participants}

The eight students who took part in this study were recruited using snowball sampling. I first met Sieng, a 17 year-old tenth grader through a social worker with the Catholic Social Services. Sieng introduced me to three other participants. I approached the other four participants while observing their ESL classes. In this sense, participants were selected based on their interests in speaking with me about their experiences in school. While I observed recognizable patterns throughout the ESL population at the school, it should be stated that other students may not hold the same views as those represented by the eight students in this study.

All of the student participants belonged to one of several ethnic minority groups indigenous to Vietnam who also fought alongside of U.S. troops during the Vietnam conflict. Many ethnic minority groups in Vietnam have in decades since the Vietnam War protested against the Vietnamese government over land rights, religious freedoms, and access to social services including education. The resettlement of Vietnamese Central Highlander refugees in the U.S. began in 1986 after a group of American veterans traveled to a refugee camp in Thailand 
and requested their relocation to the U.S. Larger groups were resettled in the state where this research was conducted between 1992 and 2006 through an Orderly Departure Program agreement between the U.S. and Vietnamese government.

Table 1

Characteristics of students in this study

\begin{tabular}{lccccccc}
\hline Name & Gender & Age & Grade & $\begin{array}{c}\text { Length of } \\
\text { Residence } \\
\text { in U.S. (yrs) }\end{array}$ & $\begin{array}{c}\text { Schooling } \\
\text { in Vietnam } \\
\text { (yrs) }\end{array}$ & $\begin{array}{c}\text { Ethnic } \\
\text { Group/Language }\end{array}$ & G.P.A. \\
\hline Dah & M & 19 & 11 & 2 & sporadic & Bnhar & 1.2 \\
Gar & F & 18 & 11 & 6 & 0 & Mnong & 1.8 \\
H'Yin & F & 19 & 12 & 4 & 3 & Jarai & 2.5 \\
Khuih & M & 18 & 12 & 5 & 2 & Mnong & 3.0 \\
Moung & F & 19 & 10 & 1 & 2 & Rhade & 1.9 \\
Sieng & M & 17 & 10 & 5 & sporadic & Mnong & 1.0 \\
Tem & F & 19 & 11 & 1 & 4 & Rhade & 2.0 \\
Vit & M & 17 & 10 & 6 & 1 & Mnong & 1.5 \\
\hline
\end{tabular}

Although the students were from four different ethnic groups, they shared similar immigration histories, and educational backgrounds. Most teachers, peers, and school administrators regarded them as one monolithic group of Vietnamese refugees. Four of the students spent time in refugee camps in Cambodia, and two came to the U.S. as part of the Family Reunification Act to join family members who had received asylum status and were already resettled in the U.S. The eight students lived in the same public housing unit, and each of their families received support from the Catholic Social Services, which provided adult English language lessons, employment assistance, and translation services.

Each of these students had missed two or more years of schooling in Vietnam or during the resettlement process and were designated by the school district as Students with Interrupted Formal Education (SIFE). All newcomer SIFE students at the high school level were placed in $9^{\text {th }}$ grade regardless of age. Students could enroll in high school until they are 21 , and those who did not graduate before then aged out, but could complete a GED at a local community college. ELL students were enrolled in one ninety-minute ESL class, which they attended daily, and the remainder of their coursework consisted of mainstream, or non-ESL, classes. Classes included "tech prep" math, algebra, earth sciences, biology, civics, world history, U.S. history, gym, family consumer sciences, Junior Reserve Officer Training Corps (JROTC), and art.

\section{Data Collection and Analysis}

As a qualitative study that took place over the course of one school year, I used ethnographic methods to develop a "thick description" (Geertz, 1973) of the school setting and of the students' identities in relation to language learning. Data were collected primarily through observations and interviews, and my role at the school was that of participant-observer. I observed and documented in field notes aspects of the students' school days, including time spent in various classrooms, in the hallways, and on the school grounds. I shadowed the students a total of 94 hours in four separate ESL classes (2 newcomer classes, ESL 1, and one ESL 2 class), tech math, algebra, earth science, civics, world history, and JROTC classes during the fall and spring 
semesters. I also did frequent, brief post-observation check-ins with students and teachers to verify my interpretations of what I observed. I conducted three separate hour-long interviews with each of the eight students (one during the fall semester, and two during the spring semester). In addition, I conducted separate thirty-minute interviews with nine teachers and an assistant principal. In the end, data consisted of 320 pages of written field notes and 20 hours of transcribed interviews. In addition to observation and interview data, I examined students' course schedules and transcripts to get a sense of how the school defined academic competence.

Data analysis occurred in several stages. Following methods outlined by Patton (2002) and Heath and Street (2008), upon transcription of interviews, I read through the data and generated codes from interview responses, background literature, and the conceptual framework. I then engaged in what Polkinghorne (1995) has called "analysis of narrative," moving "from stories to common elements" between stories, looking for recurring themes and concepts, as well as individual differences. I also looked at contextual variables that factored into each theme. Data interpretation consisted of three continuous stages: data reduction, data display, and conclusion/verification (Miles \& Huberman, 1994). Using a constant comparative, or recursive perspective, I juxtaposed data from observations and interviews with my underlying assumptions or hunches, as well as theories and concepts from the literature to create a dialogue between existing explanations and ongoing data collection and analysis (Heath \& Street, 2008). I then analyzed themes within the broader context of school to offer more nuanced portraits of language learning and the cultural practice of smartness that bore on these students' experiences in school. My analyses are based on the students' and teachers' words as well as my observations of them; they are also naturally, influenced by my subject position and positioning by those I interacted with.

\section{Findings}

\section{Institutionalizing "Smartness"}

This research prioritizes the figured high school world as a localized "space of practices" (Holland et al., 1998) in which identities are tried on and negotiated. As a figured world, the school was an arena in which students' identities were shaped dialogically and through relations of power. Teachers' perceptions of students played a significant role in shaping the identities they transacted. While some teachers took pity on the students, and provided extra support in the form of after-school study sessions, others expressed resentment over having them in their classes, and left the students to fend for themselves.

The ESL teachers (Mrs. Mickelson, Mr. Dodd, Mr. Dvorak and Ms. Jones) were strong advocates for Vietnamese Central Highlander students at the school, who they perceived as particularly vulnerable within the school context because most other teachers focused on academic and behavioral challenges prevalent among non-ELL students at the school. A wave of Vietnamese Central Highlanders had left school early in recent years to pursue jobs, care for family members, or in some cases raises their own children. Ms. Michelson shared:

I think some just gave up here. They felt like little kids because they didn't get it, and like they weren't getting enough support. They were too afraid to, or didn't know how to ask for help. We tried to advocate for them, but we were working against a system. 
The system Ms. Michelson referred to consisted of district and school level programs and ideologies that prioritized addressing classroom management issues, school violence, and improving Adequate Yearly Progress (AYP) scores. Such programming failed to recognize the individual needs and strengths of many students. Mr. Dvorak continued:

These students are not as aggressive as other students in some classes, even ESL classes. Socializing is different when there's not a structured activity. Like the Latino kidswhich is the other major ESL group-will have this intense social interaction, getting out of their seats, or talking loudly. [Vietnamese Central Highlander] kids don't seem to know what to do with that time. They're kind of cowering and quiet and the other kids are way out there in terms of behavior. I feel sorry for them when they're not told what to do in their other classes. They're way out of their league, and they're too afraid to ask for, or don't know how to ask for help.

In such classrooms smartness meant being cognizant of expectations, and "knowing what to do" when instructions were not explicitly given. This failure to make expectations visible and apparent meant that the students sat often at their desks in silence, and unable to enact legitimized smartness. ESL teachers who "felt sorry" for these students offered extra assistance with homework, made home visits, and communicated with mainstream teachers about how best to work with this population. Indirectly it may have perpetuated the pervasive deficit perspective belief at the school that the students were helpless and without agency. Mr. Anderson, an assistant principal, noted that teachers stereotyped SIFE students:

Teachers think they are quiet, no trouble compared to other students, limited English, backward ... but the squeaky wheel gets the grease, and these kids don't say, "I need help." Because they don't cause trouble, though don't get help. Really, the biggest fallacy is that they are doing well.

The students were simultaneously positioned as model minorities because they were quiet and obedient, and intellectually deficient because of their lack of English language proficiency. Teachers focused on disciplining disruptive students as opposed to students who may have benefitted from opportunities to seek academic support. Some mainstream teachers expressed resentment at having ELL SIFE students in their classrooms. I observed an interaction between Ms. Jones and a social studies teacher that underscored this tension:

Ms. Jones approaches and greets Mrs. Engels at the end of a class period I have just observed. Six of Ms. Jones ESL students are in this class. Ms. Jones asks Mrs. Engels if she can make more modifications to homework and in-class worksheets for ELLs. Mrs. Engels, who is facing me, rolls her eyes and says in exasperation, "You want me to do more?!" Ms. Jones is quiet and says that she will talk later about specific ideas.

Though they presented fewer behavioral challenges than other students, teachers perceived Vietnamese Central Highlander refugees as a burden because of their academic and linguistic needs. In this sense, the students were prevented from accessing legitimized and institutionalized smartness, in spite of being a system that desired this kind of smartness from them. 
Tracking policies further exemplify how smartness, or ineptitude was conferred upon students. A counselor I met with explained that she tracked newcomer ELLs based on age, aptitude and educational background, and that newcomer ELLs were commonly placed in "tech prep," or vocational courses, such as childcare, auto mechanics, and food preparation, because of their limited language proficiency. Though students were oriented to course options and requirements for graduation, this information was often inaccessible to ELLs, from a linguistic standpoint. I observed a twenty-minute information session for sophomores on graduation requirements:

ESL students are sitting together in the front of the nearly packed auditorium. A guidance counselor goes quickly through roughly 30 PowerPoint slides on classes students need to pass in order to graduate from high school. Moung and Sieng lean forward in their seats, while Vit looks as though he is sleeping. Pockets of non-ESL students are talking loudly and it's hard to hear the counselor from where I sit, on the other side of the auditorium from Moung, Sieng and Vit. Some of the homeroom teachers try to quiet the disruptive students, while others have given up. At the end of the session the counselor passes out booklets containing the information she went over, which teachers are to discuss with their students during homeroom. There is no time for Q\&A.

Afterward, Vit, Moung and Sieng shared that the session was "too hard [to understand]," and that the counselor spoke too fast and was difficult to hear. Though they were presented with official guidelines for enacting legitimized smartness, it proved elusive to them. Again, students faced barriers to pursuing smartness, as much as they desired to do so.

In content area classrooms, participants were generally quiet throughout the class period, unless when working in groups with other Vietnamese Central Highlanders, where they spoke their native languages. I observed Sieng and Luis in an algebra class, and field notes below illustrate a classroom environment in which these two students are positioned and position themselves:

There are 28 students in this class-22 of whom are African American, four are Vietnamese Central Highlanders and two are Hispanic. Students are sitting in assigned seats in rows facing the white board. Mr. Robinson (teacher in his 30s) stands at the transparency projector and frequently reminds students in a loud voice to copy notes from his slide. He tells them that they will be quizzed on material tomorrow. Many students are out of their seats or shouting across the classroom to one another. Sieng and Luis sit quietly in front of two other Vietnamese Central Highlander ( $\mathrm{VCH})$ males in the back left corner. Sieng looks like he is taking notes, and Luis puts his head down. The two other students talk quietly with one another.

An African-American female student walks into the classroom ten minutes late and tells Mr. Robinson that she has been removed from her regular class for disruptive behavior. Mr. Robinson tells her to sit in an empty desk in the back corner near me while other students jeer in her direction. The girl sits down and pulls out her cell phone and begins to text ... I almost feel like saying something to her, but remember, this is not my role. I 
am supposed to be invisible ... I return my gaze to the other students. Her texting goes unnoticed by Mr. Robinson.

Mr. Robinson passes out a worksheet for students to complete in groups. Sieng and the two other VCH boys are in a group together with Rosalia, a Hispanic student I recognize from Ms. Dodd's ESL class. The two boys continue talking, while Sieng and Rosalia work on the assignment. Luis is still sleeping. Mr. Robinson occasionally circulates the room, but does not approach Sieng and Rosalia ... I am surprised that he doesn't attempt to wake Luis.

Although SIFE students enrolled in courses required for graduation along with other ESL and non-ESL students, more often than not they were segregated within these classrooms where teachers were seemingly ill-equipped to work with them. Luis withdrew physically and psychologically, while others often attempted to engage the material, but were distracted by disruptive classmates.

Smartness meant fluently navigating challenging coursework, some of which students approached with little or no linguistic or content background, which rendered them uncertain about their ability to succeed in school or beyond. Teachers focused on SIFE students' academic attributes - knowledge and performance - and at times used the students' language proficiency as basis for insult or neglect. Through institutional structures and discourses students learned who was smart and the advantages that go along with it, and whether they were smart themselves.

\section{"Be[ing] Smart in English"}

Holland et al. (1998) have written that "one's history-in-person is the sediment from past experiences upon which one improvises, using the cultural resources available, in response to subject positions afforded one in the present" (p. 18). Identity is thus ever-evolving in relation to different contexts, institutions, and people. In my conversations with students, stories of past experiences in Vietnam, in refugee camps, and upon resettling in the U.S., and present experiences as high school students, in after-school jobs, and in their homes and neighborhoods, often centered around hopes for their futures-hopes that served as motivation to stay in school. Khuih, shared, "I want to have a better education than my parents so I don't need to work in a factory." Khuih desires to return to Vietnam or Cambodia to work as a translator. Dah would like to pursue a career as a pharmacist. He explained, "If my language is good, I want to help my people." He would like to be a medical broker between Vietnamese Central Highlander refugees and the U.S. medical system. These aspirations hinged on learning English and graduating from a school system in which they often felt "behind," "not ready," or "not smart."

Tem was nineteen years old and a junior. She arrived in the U.S. in 2006, and had four years of formal schooling in Vietnam. She related:

I'm in school because if you don't finish school you won't learn English. And if you don't learn English you can't find a good job. My mom wants me to know a lot of English because she wants me to translate for her at the store or at the doctor's office. She has a lot of problems here. 
Tem had a six-month old baby who her older sister cared for while Tem is in school. During a visit to her home, Tem related, "School will be easier for [my baby] because I can help her more [than my parents can help me]. And she can be good in school." Tem was aware of her poor performance in school, which she attributes to her "bad English" and interrupted schooling. Learning English in spite of her challenges, however, was a means of ensuring her daughter's future success in school. Tem wanted to be a prenatal nurse because of her experiences giving birth in the U.S., and she wanted to remain in the U.S. to help other young Vietnamese Central Highlander mothers.

Moung also positioned herself within a "not smart" framework in relation to her English language proficiency. When I asked her about how she feels in her mainstream classes, Moung shared:

I go to school to learn English, but I am afraid to use English in a lot of my classes. No one understands when I speak English, and I am afraid people will get mad if I ask questions when I don't understand the teacher.

Moung's reflections suggest that she viewed herself as successful or unsuccessful in school (as "good" and "smart" or "bad" and "stupid") by how she was treated by her peers and teachers. Like Moung, Gar was afraid to ask questions in her mainstream classes, "because other students get mad or laugh when I talk, and I feel stupid." Peers lost patience and in turn chastised and excluded SIFE students because of their limited English proficiency and accented English. Tem related, "Sometimes I try to speak to American students and they don't know what I say. They say I'm speaking Vietnamese or Chinese even when I'm speaking English. So I just stay quiet." Unable to "impose reception" (Bourdieu, 1977), Tem was ashamed and ultimately isolated. "This is why I am only friends with other [Vietnamese Central Highland] kids like me. They understand what I say because I can speak my language and English with them," she concluded.

Khuih related that he was quiet in his other classes, "because the kids speak English fluent and I don't want to say something to embarrass myself. So I am quiet and the teachers just leave me alone. I am not smart in English." He related that his lack of participation in these classes did not equate with disinterest or lack of comprehension of the content. On the contrary, he believed that he grasped material more readily than his American peers. He continued, "I listen more than other kids in my classes. I show the teacher that I want to learn even if I don't understand everything. And I think that I learn more than other kids." Khuih consciously projected a model minority identity even in situations where his ability to use English was limited. H'yin related, "A lot of kids just want to drop out of school and get a job. Me, I just want to learn English so I can help people in life."

From a different perspective, Moung lamented, "American kids understanding everything. They're smarter than [us] because we don't speak English very well. It's hard because sometimes people don't understand me even when I speak English. They think I'm stupid." Gar explained, "Like if a teacher asks you a question and you don't know the answer, [other students] say 'you're so stupid!' They say this all the time!"

H'yin likewise asserted that she had many more opportunities in the U.S. than in Vietnam, and that graduating from high school was key to attaining her goal of becoming a doctor. However, speaking in class was a source of anxiety for H'yin: 
I don't talk in class. Even when the teacher asks me questions I just give a short answer, or say "I don't know." Because it's easier, and I don't have to talk a lot. I'm afraid that my grammar is not correct, and I don't like to talk to people a lot in English. I want to be like other students, too, like talk in class and have fun, too. But I'm scared to talk, like people will laugh when I make mistakes. And they don't understand my accent.

Peers commented on the students' language proficiency in ways that were public and humiliating and detrimental to their self-esteem and their desire to remain in school.

On the contrary, Vit commented that when he first arrived in the U.S. he equated English language proficiency with intelligence. Now, he explained, "smart means being interested in school and not cutting up in class. Asian students at this school are smarter than American kids because they care about school." Vit understood what he perceived to be benefits of projecting a model minority identity. For him, intelligence entailed demonstrating a desire to learn in an environment where he believed many of his classmates did not, or were not encouraged to do so

Sieng believed that teachers found him quiet and cooperative, and gave him passing grades because he worked hard and tried to do well. He did not believe he was ready to be promoted to the next grade in all cases, however. While he benefited from the model minority stereotype, it proved detrimental to his ability to grasp academic language and content. I asked Mr. Robinson, Sieng's algebra teacher, about Sieng's progress in a class I observed: "Sieng is a really good kid," he related, "and he tries really hard. But he just doesn't get it. It seems like he understands the language, but he doesn't get the content." His teacher was doubtful that he would pass the class. Comparing refugee ELLs with other peers, Sieng shared:

How we feel is different from how American people feel. And American kids are smarter than me. In Vietnam I didn't even go to school, and that's why I'm not smart. But if American kids are born here, they are smart, maybe because their parents are smart and they be smart too. I don't think I'm smart ... because I'm a refugee and I don't speak good English.

Sieng and other students faced a contradictory path built upon a limited definition of smartness. They were expected to complete coursework required for graduation, which necessitated a mastery of academic English. Because of school structures and language ideologies inherent to them, negative or misguided stereotyping, and lack of support from teachers and peers, most of the students internalized feelings of being intellectually inferior. They viewed themselves as more mature than their peers, but they were infantilized by powerladen practices and interactions that underscored their incapability. The students also came to see themselves as better behaved than their peers, but incapable, and unimportant.

\section{Culturally Relevant Smartness}

Identities are fluid and context-dependent, and aspects of one's identity become more or less prominent according to their relevance in different spaces. The ESL classroom was a space in which students asserted and embodied what I call culturally relevant smartness. After I observed one of her ESL 1 classes, Mrs. Mickelson shared: 
In my class they open up more than in their other classes. I think they know more how to act because they are with other ESL students and other SIFE students. And we let them work together by language group to help each other translate new words, and they feel more self-confident because they are learning and helping each other, which is what many of them do in their cultures. So I think that helps.

Interview data with students supported this conclusion: Dah explained:

In ESL there are a lot of [Vietnamese Central Highlanders], and I talk a lot. Sometimes I speak Vietnamese and Bnhar in ESL when I don't know the English word. I am more relaxed in my ESL class because it's just English and not other subjects too. The teacher lets me use my language when I need to.

Dah rationalized smartness as being able to move with ease between English and Bnhar. ESL classes were transnational spaces where students practiced culturally relevant smartness through language use as a means of conveying allegiance, sharing information, or subverting teachers and peers. Tem, Moung and Gar spoke Rhade or Mnong to each other when they did not want teachers and American or other ESL students to understand. Gar shared:

Usually I am embarrassed to speak my language (Mnong) around American people. They say, "Stop speaking Chinese! Ching chong!" But sometimes I speak with my friend in math class so we can figure out the work and talk about other kids, and they don't know what we're saying. Then I like speaking my language, and the teacher don't care.

For Gar native language use is a coping mechanism, a tool for accessing and sharing information, working through academic content, and building a powerful social network. The ability to code switch between English and Mnong with friends allows Gar to access academic content more freely than when in English-only contexts.

Students also used their native languages in cases where they were called on to translate for students who were less proficient in English. In one earth science class I observed, the teacher asked Sieng to translate directions for a new Vietnamese Central Highlander student with seemingly little English language proficiency. I asked Sieng after class what language he used with the student given that he and the student do not speak the same language, and that neither he nor the student are proficient in Vietnamese. He related that he explained the directions in simple English, mixed with some Vietnamese words that both he and the other student knew.

As newcomers, eight students in this study struggled to learn and make sense of the rules of engagement shared references of their teachers and peers. They also engaged culturally relevant smartness by asserting model minority dispositions, through use of their native languages, and through collective practices, such as working collaboratively on assignments, or translating for one another. I argue that these practices enabled them to persist in a school environment that consistently defined them as both desired and undesirable, as well-behaved, but unintelligible and incapable. 


\section{Implications and Conclusion}

Language learning in any context is inherently tied to issues of power and legitimacy (Bourdieu, 1991), and opportunities for language learners to speak and be heard are power-laden in contexts where they are in a minority. In my research, smartness operated as a tool of social positioning and of social control. The students were simultaneously positioned by teachers and peers as model students who are well-behaved and try hard, and by their perceived deficits, such as limited English proficiency and limited formal education. Holland et al. (1998) argue, discourses "imposed upon people, through recurrent institutional treatments and within interaction, to the point that they become self-administered" (p. 62). Goals and aspirations become stifled by institutional discourses that signal intellectual inferiority. Because of this systematic deficit perspective, the students also came to see themselves through a similar lens - as better behaved than their peers, but incapable, and unimportant. Being positioned this way made them in some ways compliant to a system that ultimately did little to make aspirations available for many students, including ELL SIFE students.

However, while it is easy to imagine the students as victims of discriminatory school structures, and with little personal agency in the face of a system that did not understand them or their needs and strengths, they actively, albeit quietly, located spaces - the ESL classroom where they enacted smartness on their own terms, by code-switching, or translating for newer students. In addition to being a coping mechanism, and a language learning strategy, I also suggest that code switching was an identity tool for these students. In spite of their strong desire to learn English, these students retained a Vietnamese Central Highlands refugee linguistic identity with one another, congruent with culturally relevant smartness. Code-switching allowed them to bring multiple aspects of their histories in person (Holland \& Lave, 2001) into their school identities.

Toohey (2001) has written, 'Learners' identities have definite and observable effects on what they can do in classrooms, and what kinds of positions as legitimate peripheral participants in classrooms they can occupy, and therefore, how much they can 'learn"” (p. 74). This implies that educators should attempt to build communities in which powerful positions are available to all students. The fact that many teachers at the school where this study took place were unwilling or unsure of how to work with ELL SIFE students suggests that this group of students will continue to struggle in and beyond school. Schools - not just ESL teachers-must bear greater responsibility in welcoming, supporting, and listening to ELLs. Teachers must engage in culturally responsive (Gay, 2000) and critical language pedagogy (Freire, 1971; Pennycook, 2001) that recognizes and validates the backgrounds of students while engaging real-life issues. What is more, teachers must work to build greater interaction between ELL and native speaking students in mainstream classes so that students can learn from one another.

Discourse and structures prevalent in U.S. schools equate language and race with smartness and achievement. Scholars and educators should consider how students who are relative newcomers aptly negotiate and deploy racial discourse and stereotypes in efforts to position themselves against their peers. Students like those in this study are not always passive even if they appear to be so, nor does passivity equate with disengagement or being "not smart." Indeed, students used silence as a means of avoiding language discrimination, but also as a means of engaging alternative ways of learning and knowing through observation and reflection. The experiences of these students suggest a need to reconceptualize the notion of smartness from 
its assimilationist, exclusionary, and competitive orientation towards a more inclusive definition that scrutinizes the right of a select few to impose reception on the rest (Bourdieu, 1991).

\section{References}

Anderson, A. (2004). Resilience. In R. Hamilton \& D. Moore (Eds.), Educational interventions for refugee children (pp. 53-63). London, UK: Routledge.

Bigelow, M. (2010). Mogadishu on the Mississippi: Language, racialized identity and education in a new land. New York, NY: Blackwell-Wiley.

Blommaert, J. (2006). Language policy and national identity. In Ricento, T. (Ed.), An introduction to language policy: Theory and method (pp. 238-254). Malden, MA: Blackwell.

Bourdieu, P. (1977). The economics of linguistic exchanges. Social Science Information, 16, 645-668.

Bourdieu, P. (1991). Language and symbolic capital. Cambridge, MA: Harvard University Press.

Centrie, C. (2004). Identity formation of Vietnamese immigrant youth in an American high school. El Paso, TX: LFB Scholarly Publishing.

Crawford, J. (2004). Educating English learners: Language diversity in the classroom. Los Angeles, CA: Bilingual Education Services.

Duff, P. (2008). Language socialization, participation and identity: Ethnographic approaches. In M. Martin-Jones, A-M.de Mejia, \& N. Hornberger (Eds.), Encyclopedia of language and education, Vol. 3: Discourse and education (pp. 107-119). New York, NY: Springer.

Freire, P. (1971). Pedagogy of the oppressed. New York, NY: Continuum.

Gay, G. (2000). Culturally responsive teaching: Theory, research, and practice. New York, NY: Teachers College Press.

Geertz, C. (1973). The interpretation of cultures: Selected essays. New York, NY: Basic Books.

Gould, S. J. (1996). The mismeasure of man. New York, NY: Morton.

Harklau, L. (2000). From the "good kids" to the "worst": Representations of English language learners across educational settings. TESOL Quarterly, 34, 35-67.

Heath, S. B., \& Street, B. V. (2008). On ethnography: Approaches to language and literacy research. New York, NY: Teachers College Press.

Holland, D., Lachicotte Jr., W., Skinner, D., \& Cain, D. (1998). Identity and agency in cultural worlds. Cambridge, MA: Harvard University Press.

Holland, D., \& Lave, J. (Eds.). (2001). History in person. Enduring struggles, contentious practice, intimate identities. Santa Fe, NM: School of American Research Press.

Kinchloe, J., Steinberg, S. R., \& Villaverde, L. E. (1999). Rethinking intelligence: confronting psychological assumptions about teaching and learning. London, UK: Routledge.

Lee, S. J. (1996). Unraveling the model minority stereotype: Listening to Asian American youth. New York, NY: Teachers College Press.

Lee, S. J. (2005). Up against whiteness: Race, school, and immigrant youth. New York, NY: Teachers College Press.

Lee, S. J. (2007). The truth and myth of the model minority. The case of Hmong Americans. Narrowing the achievement gap: Issues in children's and families' lives. Narrowing the Achievement Gap: Issues in Children's and Families' Lives (pp. 171-184). New York, NY: Springer. 
Lippi-Green, R. (1997). English with an accent: Language, ideology, and discrimination in the United States. London, UK: Routledge.

Lippi-Green, R. (2012). English with an accent: Language, ideology and discrimination in the United States $\left(2^{\text {nd }}\right.$ ed.). New York, NY: Taylor and Francis.

Miles, M. B., \& Huberman, A. M. (1994). Qualitative data analysis. Thousand Oaks, CA: Sage.

Mosselson, J. (2006). Routes and Roots. New York, NY: Peter Lang.

Ngo, B., \& Lee, S. J. (2007). Complicating the image of model minority success: A review of Southeast Asian American education. Review of Educational Research, 77(4), 415-453.

Norton, B. (2000). Identity and language learning: Gender, ethnicity and educational change. Harlow, UK: Pearson.

Norton, B. (1998). Rethinking acculturation in second language acquisition. Prospect: An Australian Journal of TESOL, 13(2). 4-19.

Olsen, L. (1997). Made in America: Immigrant students in our public schools. New York, NY: The New Press.

Patton, M. Q. (2002). Qualitative evaluation and research methods. Newbury Park, CA: Sage Publications.

Pennycook, A. (2001). Critical applied linguistics: A critical introduction. Mahwah, NJ: Lawrence Erlbaum Associates.

Pierce, B. N. (1995). Social identity, investment, and language learning. TESOL Quarterly, 29(1), 9-31.

Polkinghorne, D. E. (1995). Narrative configuration in qualitative analysis. International Journal of Qualitative Studies in Education, 8(1), 12-28.

Skutnabb-Kangas, T., \& Phillipson, R. (1994). Linguistic human rights, past and present. In T. Skutnabb-Kangas, R. Phillipson \& R. Rannut (Eds.), Linguistic human rights: Overcoming linguistic discrimination (pp. 77-110). The Hague: Mouton.

Suarez-Orozco, C., \& Suarez-Orozco, M. M. (2001). Children of immigration. Cambridge, MA: Harvard University Press.

Talmey, S. (2009). Forever FOB? Resisting and reproducing the Other in high school ESL. In A. Reyes \& A. Lo (Eds.), Beyond yellow English: Toward a linguistic anthropology of Asian Pacific America (pp. 347-365). New York: Oxford University Press.

Toohey, K. (2000). Learning English at school: Identity, social relations and classroom practice. Clevedon, UK: Multilingual Matters.

Tuan, M. (1998). Forever foreigner or honorary whites? The Asian ethnic experience today. New Brunswick, NJ: Rutgers University Press.

Uy, P. (2009). Asian American dropouts: A case study of Chinese and Vietnamese high school students in a New England urban school district. AAPI Nexus Journal Special Issue on K-12 Education, 7(1), 83-104.

Valdés, G. (2001). Learning and not learning English: Latino students in American schools. New York, NY: Teachers College Press.

Valenzuela, A. (1999). Subtractive schooling: U.S.-Mexican youth and politics of caring. Albany, NY: State University of New York Press.

Varghese, M., Morgan, B., Johnston, B., \& Johnson, K. (2005). Theorizing language teacher identity: Three perspectives and beyond. Journal of Language, Identity, and Education, 4(1), 21-44.

Wortham, S., Murillo Jr., E. G., \& Hamann, E. T. (Eds.). (2002). Education in the new Latino diaspora: Policy and the politics of identity (Vol. 2). Westport, CT: Ablex Publishing. 


\section{Notes}

${ }^{1}$ Pseudonyms are used throughout this article to protect confidentiality.

About the Author

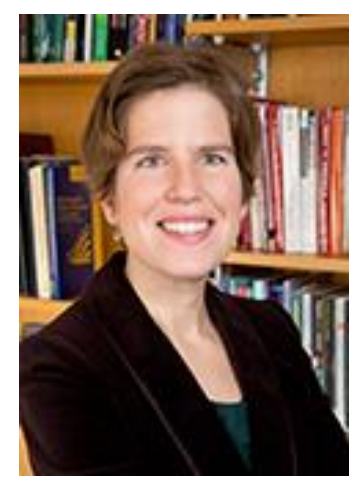

Liv Thorstensson Dávila is a Clinical Assistant Professor in the Department of Curriculum at the University of Illinois at UrbanaChampaign. Her research examines the intersection of language learning and identity among immigrant and refugee students. While her work mainly focuses on adolescent English learners in U.S. high schools, she is currently conducting on-going research in Sweden on bilingual education among immigrants and refugees in a linguistically and culturally isolated elementary school and community. 


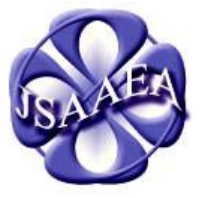

Volume 8 (2013)

\section{Journal of Southeast Asian American Education \& Advancement}

\author{
WwW.JSAAEA.org
}

\section{Editor}

Dr. Wayne E. Wright

University of Texas at San Antonio

Associate Editors

Dr. Chhany Sak-Humphry

University of Hawaii at Manoa

Dr. Phitsamay Sychitkokhong Uy

University of Massachusetts, Lowell

Book Review Editor

Dr. Vichet Chhuon

University of Minnesota

Creative Works Editor

Bryan Thao Worra

Lao Assistance Center

\section{Special Advisor}

Gregory Green

Curator, Echols Collection on Southeast Asia, Cornell University Library

Journal Manager

Yeng Yang

University of Texas at San Antonio
A peer-reviewed

scholarly journal published by the

National Association

for the Education \&

Advancement of

Cambodian, Laotian,

and Vietnamese

Americans (NAFEA)

Comments and questions for the editorial staff may be directed to jsaaea@ lists.sis.utsa.edu

\section{Editorial Review Board}

\author{
Dr. Steve Arounsack \\ California State University, Stanislaus \\ Dr. Phala Chea \\ Lowell Public Schools \\ Dr. Loan Dao \\ University of Massachusetts, Boston \\ Dr. Changming Duan \\ University of Missouri, Kansas City \\ Dr. Jeremy Hein \\ University of Wisconsin - Eau Claire \\ Dr. Samlong Inthaly \\ Minneapolis Public Schools \\ Dr. Ketmani Kouanchao \\ Mr. San Jacinto College
}

\author{
Dr. Carl L. Bankston III \\ Tulane University \\ Dr. George Chigas \\ University of Massachusetts, Lowell \\ Dr. Hien Duc Do \\ San Jose State University \\ Dr. Sophal Ear \\ U.S. Naval Postgraduate School \\ Dr. Nancy H. Hornberger \\ University of Pennsylvania \\ Dr. Peter Nien-Chu Kiang \\ University of Massachusetts, Boston \\ Dr. Kevin K. Kumashiro \\ University of Illinois, Chicago
}




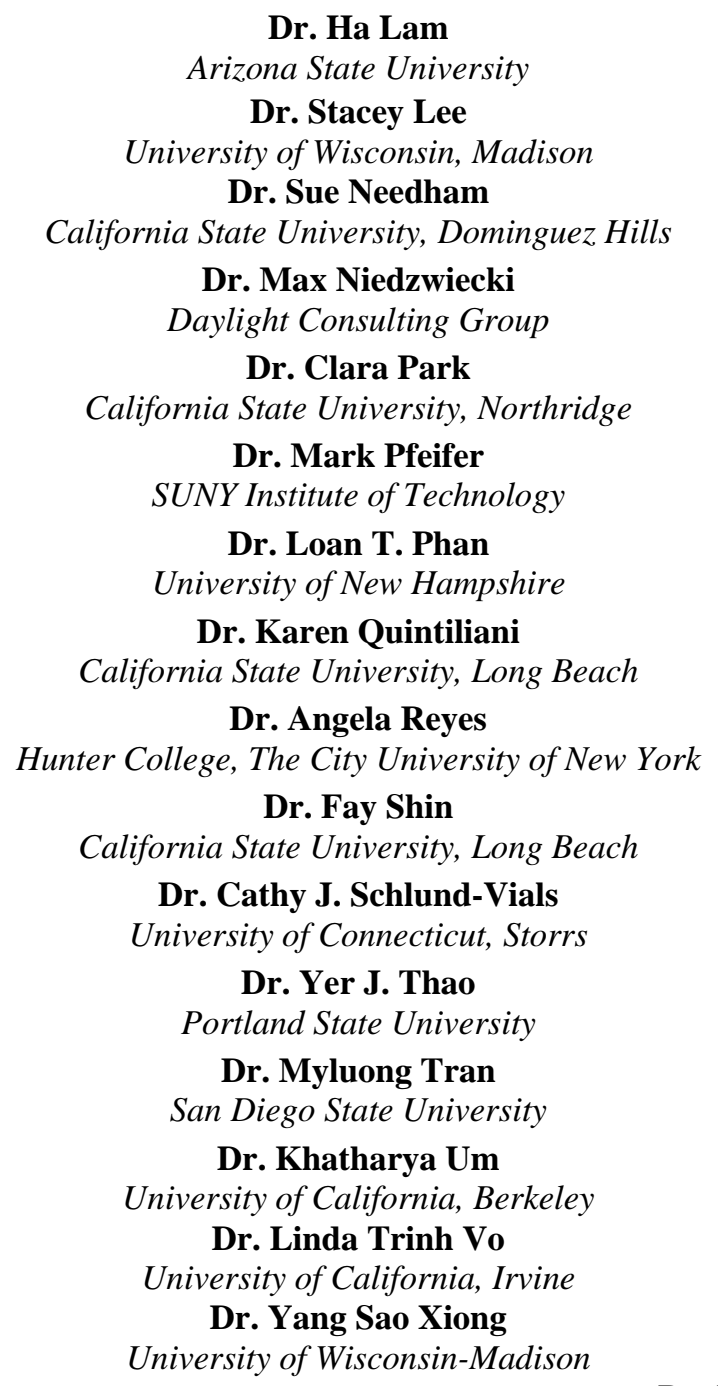

Dr. Ha Lam

Arizona State University

Dr. Stacey Lee

University of Wisconsin, Madison

Dr. Sue Needham

California State University, Dominguez Hills

Dr. Max Niedzwiecki

Daylight Consulting Group

Dr. Clara Park

California State University, Northridge

Dr. Mark Pfeifer

SUNY Institute of Technology

Dr. Loan T. Phan

University of New Hampshire

Dr. Karen Quintiliani

California State University, Long Beach

Dr. Angela Reyes

Hunter College, The City University of New York

Dr. Fay Shin

California State University, Long Beach

Dr. Cathy J. Schlund-Vials

University of Connecticut, Storrs

Dr. Yer J. Thao

Portland State University

Dr. Myluong Tran

San Diego State University

Dr. Khatharya Um

University of California, Berkeley

Dr. Linda Trinh Vo

University of California, Irvine

Dr. Yang Sao Xiong

University of Wisconsin-Madison

Dr. Jonathan H. X. Lee

San Francisco State University

Dr. Monirith Ly

Texas State University-San Marcos

Dr. Bic Ngo

University of Minnesota

Dr. Leakhena Nou

California State University, Long Beach

Dr. Isabelle Thuy Pelaud

San Francisco State University

Dr. Giang Pham

University of Minnesota

Dr. Bounlieng Phommasouvanh

Minnesota Department of Education

Dr. Kalyani Rai

University of Wisconsin, Milwaukee

Dr. Soveacha Ros

Royal University of Phnom Penh

Dr. Nancy J. Smith-Hefner

Boston University

Dr. Christine Su

Ohio University

Dr. Loan Tran

University of California, Riverside

Dr. Tinou Tran

Alief Independent School District

Dr. Silvy Un

Frost Lake Elementary School

Dr. Terrence G. Wiley

Center for Applied Linguistics

Dr. Zha Blong Xiong

University of Minnesota

Dr. Kou Yang

California State University, Stanislaus

\section{Doctoral Student Editorial Review Board}

Sovicheth Boun

University of Texas at San Antonio

Keo Chea-Young

University of Pennsylvania

Peter Tan Keo

Columbia University

Minh Mai

University of Wisconsin-Madison

Hoa Nha Nguyen

Boston College

Vanna Som

Harvard University
Virak Chan

University of Texas at San Antonio

Annie BichLoan Duong

San Joaquin County Office of Education

Ravy Lao

University of California, Santa Barbara

Thien-Huong Ninh

University of Southern California

Malaphone Phommasa

University of California, Santa Barbara

Alisia Tran

University of Minnesota

Krissyvan Truong

Claremount Graduate University 